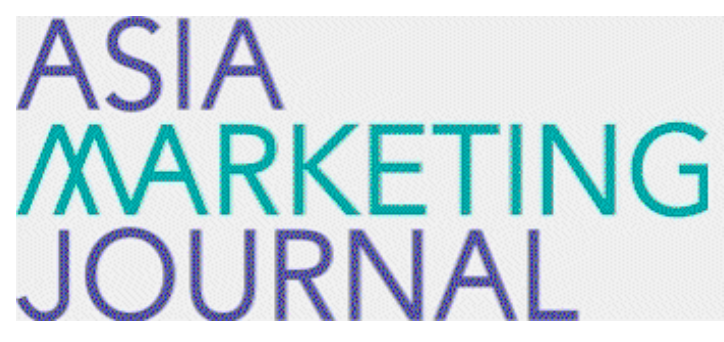

ASIA MARKETING JOURNAL

Volume 15 | Issue 3

Article 6

$10-30-2013$

\title{
Effects of Product Number and Brand Breadth on the Evaluations of an Extended Product
}

Min Sun Yeu

Hye Yeon Yuk

Bo Ha Kim

Yoo

Seong Wan Cho

See next page for additional authors

Follow this and additional works at: https://amj.kma.re.kr/journal

Part of the Marketing Commons

\section{Recommended Citation}

Yeu, Min Sun; Yuk, Hye Yeon; Kim, Bo Ha; Yoo; Cho, Seong Wan; Yeo, Jun Sang; and Park, Chan Su (2013) "Effects of Product Number and Brand Breadth on the Evaluations of an Extended Product," Asia Marketing Journal: Vol. 15 : Iss. 3 , Article 6.

Available at: https://doi.org/10.53728/2765-6500.1560

This Article is brought to you for free and open access by Asia Marketing Journal. It has been accepted for inclusion in Asia Marketing Journal by an authorized editor of Asia Marketing Journal. 
Effects of Product Number and Brand Breadth on the Evaluations of an Extended Product

Authors

Min Sun Yeu, Hye Yeon Yuk, Bo Ha Kim, Yoo, Seong Wan Cho, Jun Sang Yeo, and Chan Su Park 


\title{
Effects of Product Number and Brand Breadth on the Evaluations of an Extended Product*
}

\author{
Minsun $\mathrm{Yeu}^{* *}$ \\ Hyeyeon Yuk ${ }^{* * *}$ \\ Boha Kim**** \\ Jung-Hyun Yoo** \\ Seong Wan Cho* \\ Junsang Yeo* \\ Chan Su Park*
}

This paper was motivated by two gaps in the extant literature on brand portfolio planning. First, research has shown that, as the number of products connected to a brand increases, the extended product receives more favorable evaluations. However, this result was obtained by comparing two brands with different number of products while controlling the brands' breadths. Hence one may question if the above result would hold when the brand is narrow as well as broad. Second, the literature has investigated the effect of brand breadth on the perceived fit and evaluations of an extended product within a relatively limited range ("narrow vs. broad") and not considered the case of a "very broad" brand.

To address these gaps, we propose two hypotheses: 1) the effects of the number of products associated with a brand on the perceived fit and evaluations of a moderately far brand extension are moderated by the brand's breadth (H1): and 2) the relationship between a brand's breadth and a moderately far extension's perceived fit and evaluations looks like an inverse-U shape (H2).

Study 1 was conducted to test H1. Study 1 employed a $2 \times 2$ within-subjects design in which the first factor was the number of products (small (2) or large (5)), and the second factor was brand breadth (narrow or broad). We measured brand breadth as the perceived similarity among products

\footnotetext{
* This paper has been supported by KUBS Faculty Research Grant awarded to Chan Su Park.

** Ph.D. Candidate in Marketing, Korea University Business School

**** Assistant Manager. Etrade Korea

**** $\quad$ Assistant Manager. BCcard Co..Ltd.

***** Assistant Manager, Shinhancard

****** Researcher, Management Research Dept., LG Economic Research Institute

******* Associate Professor of Marketing. Dongguk University Business School

******** Professor of Marketing, Korea University Business School (chansu@korea,ac.kr), Corresponding Author
} 
associated with a brand. Participants provided the perceived fit and evaluations of an extended product. Study 2 was conducted to test $\mathrm{H} 2$ as well as to replicate Study 1 in a more general setting and with different products. It employed a $2 \times 3$ within-subjects design, in which the first factor was the number of products (small (2) or large (5)), and the second factor was brand breadth (narrow, broad, or very broad). The results from two experiments support both hypotheses.

This paper contributes to the literature on brand extensions in two ways. First, it broadens our understanding of the effects of product number and brand breadth on extended product evaluations by considering the two factors jointly. Second, we believe this study to be the first to present evidence that brand breadth can exert an inverted U-shape effect on the perceived fit and evaluations of an extended product.

The results also offer implications for marketers. First, marketers should heed the finding that adding similar products to a narrow brand does not help the brand's extension launch. Second, the finding that the relationship between brand breadth and extended product evaluations might not be linear provides practical implications. While a narrow brand should not keep launching close extensions, nor should a broad brand continue producing far extensions to broaden its breadth. A firm with a broad corporate or family brand might want to consider introducing a new brand instead of adding dissimilar products under the brand umbrella.

Key words: Brand Extension, Brand Breadth, Product Number, Experiment

\section{Introduction}

Brands are important firm assets and successfully launching brand extensions has become an invaluable tool for growth. However, they can dilute beliefs about a brand (e.g., Loken and John 1993) and do not always produce positive outcomes (e.g., Jun, Huh and Jang 2007). Firms should thus carefully develop brand extension strategies that produce the benefits while minimizing the risks, a process
Dacin and Smith (1994) call brand portfolio planning. We investigate the following two important questions regarding brand portfolio planning in this paper: (1) would it be desirable to attach many products to a brand (2) should there be a strong similarity or relatedness ${ }^{1)}$ among them?

The literature offers substantial insight into these issues. Regarding the first, several papers have shown that, as the number of products connected to a brand increases, the extended product receives more favorable evaluations

1) For brevity, we will use "similarity" hereafter. 
(e.g., Dacin and Smith 1994: Sheinin and Schmitt 1994). This is more pronounced in moderately far extensions than in close extensions (e.g., Boush and Loken 1991). Regarding the second issue, the dissimilarity among products represented by a brand name has been called "brand breadth" (Boush and Loken 1991). Research demonstrates that, for a narrow brand (i.e., one with highly similar products), the extended product receives favorable evaluations if the fit between the parent brand and the extended product is high while, for a broad brand, the extended product can obtain favorable evaluations even if the fit is not high (e.g., Dacin and Smith 1994: Meyvis and Janiszewski 2004).

Despite these results, two gaps remain in the literature. First, research has not considered the joint effects of product number and brand breadth on an extended product's evaluation, focusing instead on the separate effects of the two variables. For example, Experiment 1 in Dacin and Smith (1994), investigating the effect of product number on an extended product's evaluation, compared two brands with three and seven products while controlling the brands' breadth. The result showed that the extended product could obtain higher evaluations when the parent brand was associated with a larger number of products. However, one may question if the result of Experiment 1 would hold regardless of the parent brand's breadth. Consider the following two brandsBrand A consisting of five products (inkjet printer, black and white laser printer, color laser printer, photo printer, and label printer) and Brand B consisting of two products (inkjet printer and black and white laser printer). Now suppose that both brands extend their brands to the mobile phone category, which constitutes moderately far extensions. According to the result of Experiment 1 of Dacin and Smith (1994) mentioned above, one should expect Brand A's extension would receive more favorable $\mathrm{re}^{-}$ sponses than Brand B's because the former has a larger number of products. However, we argue Brand A's extension might not necessarily receive more favorable evaluations because an opposing force is in operation in this particular case: Brand A would more likely be perceived as a narrow "printer brand" and hence a mobile phone from the "printer brand" may be evaluated unfavorably, which could undermine Brand A's advantage of being associated with a larger number of products. Thus understanding the effects of product number and brand breadth on an extended product's evaluation requires us to take the joint effects of the two variables into account.

The other gap in the literature concerns the effect of brand breadth on an extended product's evaluation. Research has contrasted a narrow brand with a broad one to show that a broad brand holds an advantage over a narrow one in moderately far extensions (e.g., Dacin and Smith 1994; Meyvis and Janiszewski 2004). However, it is not clear if one can generalize 
the above finding to a very broad brand and assume a linear relationship between brand breadth and the favorability of an extended product's evaluation. Consider the following two brands - Brand $\mathrm{C}$ consisting of five products (printer, digital camera, scanner, copier, and DSLR camera) and Brand D consisting of five relatively dissimilar products (printer, digital camera, copier, air conditioner, and washer). If both brands launch mobile phones as extended products, will Brand D's mobile phone receive more favorable evaluations because Brand D is wider than Brand C? In fact, this question has practical relevance. The Virgin brand contains more than 300 branded companies marketing such diverse product areas as travel, lifestyle, media, mobile, money, music, health care, and alcohol. Virgin's seemingly undisciplined brand extensions have sparked debate in the wake of poor performances of some of its extensions such as Virgin Cola, Virgin Vodka, Virgin PCs, Virgin Jeans, Virgin Brides and Virgin Clothing (Keller 2012). More recently, Samsung Electronics switched its branding strategy for its domestic market from house-of-brands to corporate branding strategy by eliminating several individual product brands such as Pavv (TVs), Hauzen (air-conditioners), Yepp (MP3 players), Vluu (cameras) and Magic Station (desk-top computers). Samsung announced that Samsung brand alone would be used for these product categories (Kim 2011). Although such a move could have an advant- age of providing uniform image, one may question if it would be adequate to use Samsung brand alone in diverse products ranging from air-conditioners to cameras. In fact, Kardes and Allen (1991) conjecture that a very broad brand might be perceived as a "jack-of-all-trades" (master of none). Images and values associated with a brand name become more ambiguous and more diffuse as unrelated products are added through extensions (Ries and Trout 1981). Consequently it will have its future extended products evaluated unfavorably. However, to the best of our knowledge, few, if any, research has investigated this conjecture. If one wants to fully understand the effect of brand breadth on extended products' evaluations, therefore, the breadth of the brand needs to be extended to include a very broad brand in addition to narrow and broad ones. To address these two gaps in the literature, we have conducted two studies.

\section{Hypotheses}

\subsection{Effects of Number of Products Associated with a Brand}

Research on the effects of product number on extended product's evaluations has hypothesized a positive relationship between the two. Dacin and Smith (1994), for instance, provide 
two justifications: first, when a brand introduces an extended product, it implicitly posts future sales of other products associated with the brand as collateral for the quality of the extension. As the collateral base increases, consumers will expect higher quality from the extension and provide more favorable evaluations. Second, as the number of products associated with a brand increases, consumers will be exposed to the brand more often. The increased familiarity following exposure (through the "mere exposure effect": Zajonc 1980) will produce more favorable evaluations of the extension.

However, as discussed, the study has not explicitly considered the possibility that the above relationship could be moderated by brand breadth. Boush and Loken (1991) predict that the perceived typicality ${ }^{2)}$ of an extended product should be more extreme for narrow brands than for broad brands. Specifically, an extended product essentially the same as the brand's current products should be perceived as more typical if the brand is narrow than if the brand is broad. However, an extended product very different from the brand's current products should be perceived as less typical if the brand is narrow than if the brand is broad.

Thus, the research finding that the number of products associated with a brand positively affects extended products' evaluations is probably applicable only to broad brands. We do not expect the same result to hold for narrow brands. Suppose that the Brands A and B mentioned previously were initially equally narrow, consisting of two products - an inkjet printer and a black and white laser printer. Suppose that Brand $\mathrm{A}$ then added three new products, a color laser printer, a photo printer, and a label printer which are all printer products. Consumers would likely perceive a stronger similarity among Brand A's products because the number of attributes shared by the five already similar products would be higher than for Brand B which still consists of two products, an inkjet printer and a black and white laser printer. In other words, Brand A would more likely to be perceived as a "printer brand" specializing in printer products. Brand A would thus face more difficulties than Brand B in introducing a moderately far brand extension (e.g., a mobile phone). In short, increasing the number of products associated with a narrow brand would produce two opposing effects in a moderately far brand extension: collateral and exposure effects (Dacin and Smith 1994) favoring the brand associated with more products and the extreme typicality effect (Boush and Loken 1991) undermining the advantage of being associated with more products. We thus propose the following hypothesis:

\section{H1: The positive effects of the number of}

2) Boush and Loken (1991) use the term "typicality" to mean similarity or fit. 
products associated with a brand on the perceived fit and evaluations of a moderately far brand extension will be moderated by the brand's breadth. Specifically. the effects will be greater for a broad brand than for a narrow brand.

\subsection{Effects of Brand Breadth}

Research on the effects of brand breadth on the perceived fit and evaluations of an extended product has contrasted narrow brands with broad ones to find that a broad brand holds an advantage in moderately far brand extensions (e.g., Boush and Loken 1991: Meyvis and Janiszewski 2004).

The above results imply a linear relationship between a brand's breadth and an extension's evaluation, but it is not certain that this would hold for a very broad brand. A broad brand produced through a series of dissimilar brand extensions could be perceived as having diverse skills over diverse product categories, giving it the capability to successfully enter a new product category. Therefore, a moderately far extension from such a brand might be evaluated favorably. However, Kardes and Allen (1991) conjecture a limit for this process. A brand that constantly introduces dissimilar extensions may eventually be perceived as a "jack-of-alltrades" (and master of none). Images and values associated with a brand name become more ambiguous and more diffuse as unrelated products are added through extensions (Ries and Trout 1981). Further extensions could then be viewed negatively. Hence, we propose the following hypothesis:

H2: The relationship between a brand's breadth and a moderately far extension's perceived fit and evaluations will look like an inverse- $U$ shape. Specifically, a broad brand would have higher perceived fit and evaluations of the extension than a narrow brand or a very broad brand.

\section{Study 1}

We conducted Study 1 to test H1. Study 1 employed a $2 \times 2$ within-subjects design in which the first factor was the number of products (small (2) or large (5)), and the second factor was brand breadth (narrow or broad). We chose the within-subjects design for statistical efficiency. In the context of brand extension research, the within-subjects design holds an additional advantage of providing higher external validity over the between-subjects design because the former emulates everyday purchase decision-making scenarios in which consumers are faced with different extensions from different parent brands. Previous research has often used the within-subjects design either in full (e.g., Sheinin and Schmitt 1994) or 
in part (e.g., Broniarczyk and Alba 1994: Liang, Cherian and Fu 2010: Morrin 1999: Sood and Keller 2012).

\subsection{Stimuli and Pre-test}

We measured brand breadth as the perceived dissimilarity among products associated with a brand (e.g., Meyvis and Janiszewski 2004). However, it poses a significant challenge to vary brand breadth separately from the number of products. For example, a brand with just two products should have more or less the same breadth (i.e., dissimilarity among the products) with a brand with five products. To meet the challenge we adopted the method of measuring family resemblance originally proposed by Tversky (1977) but later adapted by Ahn and $\mathrm{Ha}$ (2001) to construct product sets with different levels of similarity.

Specifically, we started by measuring the pairwise similarity among nine products - soap, hand sanitizer, shampoo, body wash, foam cleanser, air freshener, fabric softener, liquid detergent. and tissue. Sixty-nine college students at a large university participated in the measurement for course credit.

The participants evaluated the pair-wise similarities among the nine products using a 7 -point scale (1 "very different" and 7 "very similar"). We then constructed two hypothetical brands, Brand C (narrow, with five products) and Brand D (broad, with five products), with soap in common and four other products in their product portfolios. To determine the remaining four products for Brands $\mathrm{C}$ and $\mathrm{D}$, we constructed 70 sets $\left({ }_{8} \mathrm{C}_{4}\right)$ of five products, one of which was always soap. For each set, we computed the total similarity score by summing $10\left({ }_{5} \mathrm{C}_{2}\right)$ pair-wise similarity scores. We assigned the set with the highest (or lowest) total similarity score to Brand C (or D: please refer to Figure 1). Finally, we constructed Brand A (narrow, with two products), consisting of soap and shampoo, which had the lowest pair-wise similarity score with soap among Brand C's products. Likewise, we constructed Brand B (broad, with two products) to include soap and tissue, which had the lowest pair-wise similarity score with soap among Brand D's products (please refer to Figure 1). Boush and Loken (1991) suggest that brand breadth can be specified as having both range (i.e., the difference between the two most different products) and variability (i.e., the pairwise differences squared and summed). In our study, Brand A (B) was constructed to have the same range as Brand C (D).

To see if the four brands were constructed as intended, we obtained brand breadth measurements from 69 college students." Thirty five students measured overall similarities among

3) This group of 69 students was different from those who participated in the family resemblance task. 
〈Figure 1〉 Stimuli for Study 1

\begin{tabular}{|c|c|c|c|}
\hline & \multicolumn{2}{|c|}{ Number of Products } \\
\hline & & Small (2) & Large (5) \\
\hline \multirow{2}{*}{$\begin{array}{c}\text { Brand } \\
\text { Breadth }\end{array}$} & Narrow & $\begin{array}{c}\text { Brand A } \\
\text { Soap, Shampoo } \\
(6.13)^{*}\end{array}$ & $\begin{array}{c}\text { Brand C } \\
\text { Soap, Hand Sanitizer } \\
\text { Body Wash, } \\
\text { Foam Cleanser, } \\
\text { Shampoo } \\
(6.13)\end{array}$ \\
\hline & Broad & $\begin{array}{c}\text { Brand B } \\
\text { Soap, Tissue } \\
(6.74)\end{array}$ & $\begin{array}{c}\text { Brand D } \\
\text { Soap, Air Freshener. } \\
\text { Fabric Softener, } \\
\text { Liquid Detergent, } \\
\text { Tissue } \\
(6.74)\end{array}$ \\
\hline
\end{tabular}

* Range of Brand Breadth (i.e., average dissimilarity rating of the two most dissimilar products of each brand).

products in Brands $\mathrm{A}$ and $\mathrm{B}$, using the same 7 -point scale as above. The remaining 34 students measured overall similarities among products in Brands $\mathrm{C}$ and D. We formed brand breadth scores by reverse coding the similarity rating. As expected, Brand $\mathrm{B}$ was broader than Brand $\mathrm{A}\left(\mathrm{M}_{\mathrm{A}}=4.69<\mathrm{M}_{\mathrm{B}}=6.06, p<\right.$ 0.01 ), and Brand D was broader than Brand $C$ $\left(\mathrm{M}_{\mathrm{C}}=2.76<\mathrm{M}_{\mathrm{D}}=5.29, p<0.01\right)$.

\subsection{Procedure}

A total of 80 college students at a large university participated in the study for course credit. The participants read an instruction that the survey intended to measure consumers' responses toward a new product. They were provided with a separate sheet of paper which displayed the four fictitious brands (named A, B, C, D, respectively) and products marketed by them (Appendix shows the actual stimuli card). They were told that these are actual products marketed by these companies and the real brand names were not disclosed by the requests of the companies. They then evaluated the similarities among the products marketed by each of the four fictitious brands using the same 7-point scale as above. We formed brand breadth scores by reverse coding the similarity ratings. Participants were randomly assigned to different versions of the questionnaire, which varied the order in which the four brands were presented.

The participants then read an instruction indicating that each of the four brands had developed and was about to launch a new laun- 
dry detergent. They evaluated the perceived fit between the current products and the new product using a 7-point Likert scale ("the laundry detergent is similar to existing products of Brand $[\mathrm{A} / \mathrm{B} / \mathrm{C} / \mathrm{D}]$ ") ) and evaluated the new product itself using four 7-point Likert scales ("would be a good product," "like the product," "would like to buy the product," and "would like to recommend the product").

\subsection{Results}

We first conducted a manipulation check for brand breadth. As expected, the results showed that Brand $B$ was broader than Brand A $\left(\left(M_{A}\right.\right.$ $=2.43\left\langle\mathrm{M}_{\mathrm{B}}=4.81, \mathrm{t}[79]=-14.348, p<\right.$ 0.01 ) and that Brand $\mathrm{D}$ was broader than Brand $\mathrm{C}\left(\mathrm{M}_{\mathrm{C}}=1.85<\mathrm{M}_{\mathrm{D}}=4.86, \mathrm{t}[79]=\right.$ -16.809, $p<0.01$ ).

\subsubsection{Perceived fit}

H1 predicted that the positive effects of product number on the perceived fit and evaluations of an extended product would be moderated by brand breadth and that, specifically, the effects would be stronger for a broad brand than for a narrow brand.

The results showed that, for a broad brand, the perceived fit was significantly higher when the brand was associated with five products than when associated with two $\left(\mathrm{M}_{\mathrm{B}}=3.13<\right.$ $\left.\mathrm{M}_{\mathrm{D}}=4.91, \mathrm{t}[79]=-9.508, p<0.01\right)$. For $\mathrm{a}$ narrow brand, however, there was no significant difference in perceived fit between the five-product and two-product brands $\left(\mathrm{M}_{\mathrm{A}}=\right.$ $\left.3.34, \mathrm{M}_{\mathrm{C}}=3.19, \mathrm{t}[79]=1.136, p=0.55\right)$. Thus, H1 was supported (please refer to Figure 2). In deriving $\mathrm{H} 1$, we postulated that a narrow

〈Figure 2〉 Number of Products, Brand Breadth, and Perceived Fit

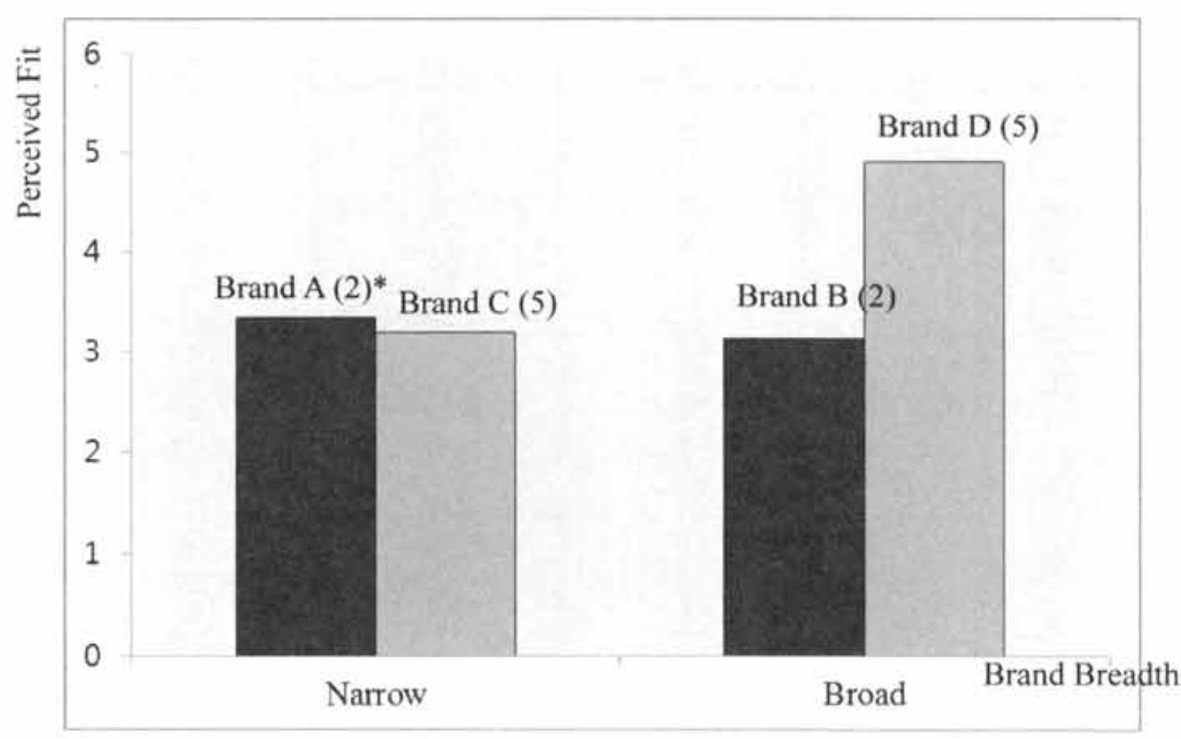

${ }^{*}$ Number of products in parenthesis 
brand with similar products added to its portfolio will be perceived as even narrower, thus leading to disadvantages in the case of a moderately far brand extension. The perceived brand breadth measures confirmed our postulation: Brand $\mathrm{C}$ was perceived as significantly narrower than Brand $\mathrm{A}\left(\mathrm{M}_{\mathrm{A}}=2.43>\mathrm{M}_{\mathrm{C}}=\right.$ $1.85, \mathrm{t}[79]=6.133, p<0.01$ ), while there was no significant difference in perceived narrowness between Brands $B$ and $D\left(M_{B}=4.81\right.$, $\left.\mathrm{M}_{\mathrm{D}}=4.86, \mathrm{t}[79]=-0.376, p=0.71\right)$. Notably, the subjects, on average, perceived Brand C narrower than Brand $\mathrm{A}$, though both brands had the same range (i.e., the differences between the two most different products were identical). The subjects might have perceived a stronger similarity among Brand C's products because the number of attributes shared by the brand's five already similar products was higher than that for Brand A, illustrating the difficulty a narrow brand with numerous products would face when attempting to introduce a moderately far brand extension.

Table 1 shows the result of a regression analysis relating the perceived fit to product number, brand breadth, and their interaction term. As predicted by H1, the interaction term is statistically significant.

\subsubsection{Evaluations of an extended product}

We found the four measurement items to have high reliability (Cronbach's $a=0.93$ ). We thus used the simple average of these items in further analyses.

We found that, for a broad brand, the extended product was more favorably evaluated when the brand was associated with five products than when associated with two $\left(\mathrm{M}_{\mathrm{B}}=\right.$ $\left.3.13<\mathrm{M}_{\mathrm{D}}=4.81, \mathrm{t}[79]=-10.340, p<0.01\right)$. For a narrow brand, however, the extended product from the five-product brand was not more favorably evaluated than that from the two-product brand $\left(\mathrm{M}_{\mathrm{A}}=3.45, \mathrm{M}_{\mathrm{C}}=3.53\right.$, $\mathrm{t}[79]=-0.644, p=0.70)$. Thus $\mathrm{H} 1$ was supported. The result of a regression analysis shows a significant interaction effect between product number and brand breadth, as predicted by $\mathrm{H} 1$ (see Table 2).

$\langle$ Table 1〉 Effects of Product Number and Brand Breadth on Perceived Fit

\begin{tabular}{cccc}
\hline & Coeff. & t-values & $p$-values \\
\hline Constant & 3.948 & 8.585 & .000 \\
Product Number & -.148 & -1.545 & .123 \\
Brand Breadth & -.334 & -2.873 & .000 \\
Prod Num * Brand Breadth & .105 & 4.221 & .000 \\
\hline
\end{tabular}

*R-squared $=0.117, \mathrm{~N}=80$ 
〈Table 2〉 Effects of Product Number and Brand Breadth on Evaluations of a Brand Extension

\begin{tabular}{cccc}
\hline & Coeff. & t-values & $p$-values \\
\hline Constant & 3.460 & 9.044 & 0.000 \\
Product Number & -0.017 & -0.209 & 0.834 \\
Brand Breadth & -0.184 & -1.901 & 0.058 \\
Prod Num * Brand Breadth & 0.070 & 3.402 & 0.001 \\
\hline
\end{tabular}

${ }^{*} \mathrm{R}$-squared $=0.139, \mathrm{~N}=80$

\section{Study 2}

Study 2 was conducted to test $\mathrm{H} 2$ as well as to replicate Study 1 in a more general setting and with different products. To test $\mathrm{H} 2$, it was necessary to divide brand breadth into three levels. Hence, Study 2 employed a 2 x 3 within-subjects design, in which the first factor was the number of products (small (2) or large (5)), and the second factor was brand breadth (narrow, broad, or very broad). Having three levels of brand breadth (instead of two) allowed us to test $\mathrm{Hl}$ in a more general setting.

\subsection{Stimuli and Pre-test}

We measured the pair-wise similarities among nine products - a printer, scanner, digital camera, copier, refrigerator, air-conditioner, television, washer, and DSLR (Digital Single-Lens Reflex) camera. A total of 57 college students at a large university participated in the measurement for course credit. As in Study 1, we constructed Brands B (a broad brand with two products), D (a broad brand with five products), B1 (a very broad brand with two products), and D1 (a very broad brand with five products) by adapting the method of measuring family resemblance proposed by Tversky (1977). Brands A and C (narrow brands, with two and five products, respectively) consisted of printer products only (please refer to Figure 3 ).

To see if the six brands were constructed as intended, we obtained brand breadth measurements from 60 college students. Of these, 30 evaluated similarities among the products associated with Brands $\mathrm{A}, \mathrm{B}$, and $\mathrm{B} 1$, and the remaining 30 evaluated similarities among the products in Brands C, D, and D1. We formed brand breadth scores by reverse coding the similarity ratings. As expected, Brand $\mathrm{B}$ was broader than Brand $\mathrm{A}\left(\mathrm{M}_{\mathrm{A}}=2.47<\mathrm{M}_{\mathrm{B}}=\right.$ 5.07, $p<0.01$ ), and Brand B1, broader than Brand $B\left(M_{B}=5.07<M_{B 1}=6.07, p<0.01\right)$. Similarly, Brand D was broader than Brand C $\left(\mathrm{M}_{\mathrm{C}}=1.67<\mathrm{M}_{\mathrm{D}}=3.70, p<0.01\right)$, and Brand D1, broader than Brand $D\left(M_{D}=3.70\right.$ $\left\langle\mathrm{M}_{\mathrm{D} 1}=5.67, p<0.01\right)$. 
〈Figure 3〉 Stimuli for Study 2

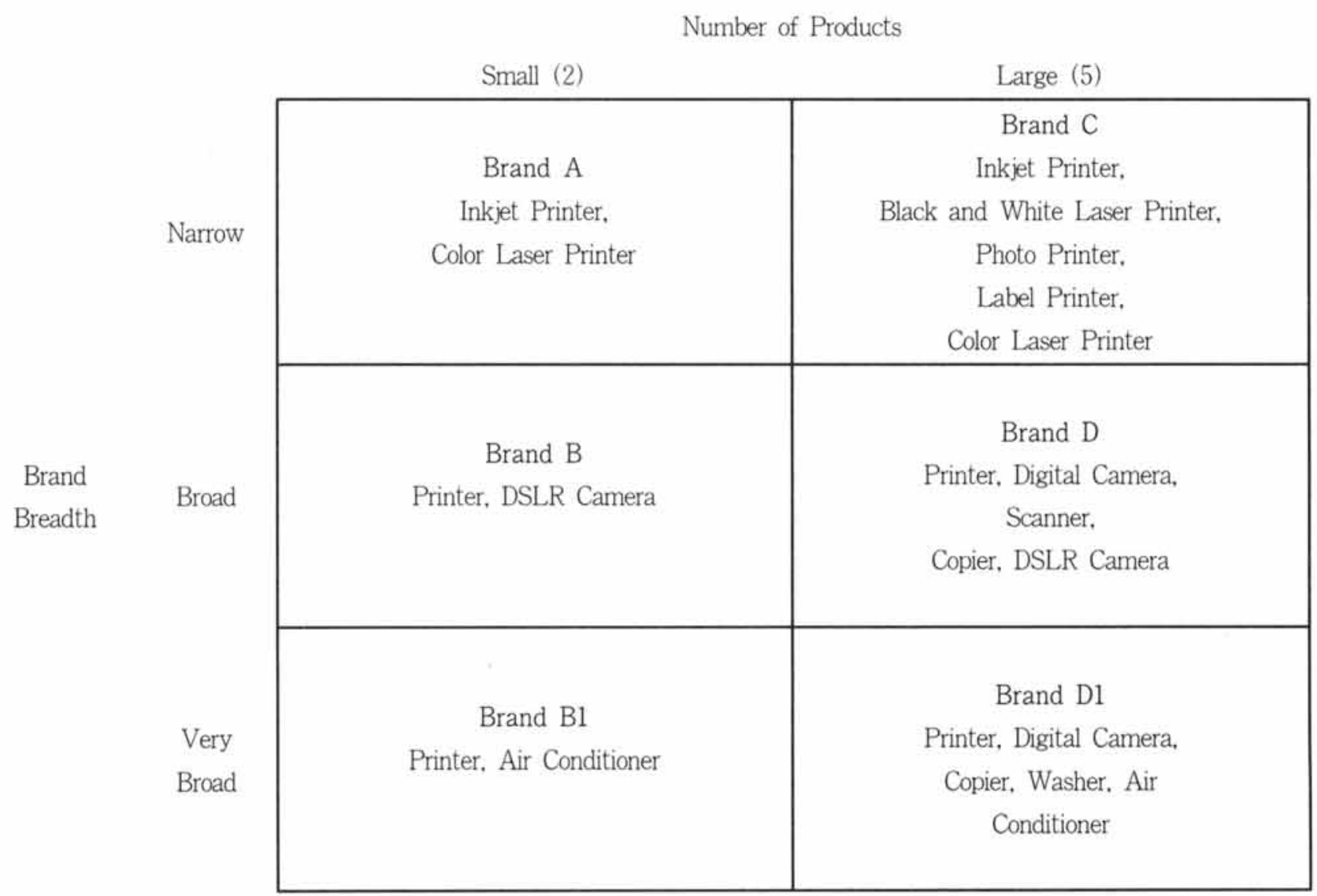

\subsection{Procedure and Results}

A total of 40 college students at a large university participated in the study for course credit. Study 2 used the same procedure and measurement scales as in Study 1.

We first conducted a manipulation check for brand breadth. As expected, the results showed that Brand $B$ was broader than Brand $A\left(M_{A}\right.$ $\left.=2.07<\mathrm{M}_{\mathrm{B}}=4.65, \mathrm{t}[39]=-9.293, p<0.01\right)$, and Brand $\mathrm{B} 1$, broader than Brand $\mathrm{B}\left(\mathrm{M}_{\mathrm{B}}=\right.$ $4.65\left\langle\mathrm{M}_{\mathrm{B} 1}=6.23, \mathrm{t}[39]=-5.684, p<0.01\right)$. Similarly, Brand D was broader than Brand C $\left(\mathrm{M}_{\mathrm{C}}=1.87\left\langle\mathrm{M}_{\mathrm{D}}=3.72, \mathrm{t}[39]=-6.640, \mathrm{p}\right.\right.$
0.01), and Brand D1, broader than Brand D $\left(\mathrm{M}_{\mathrm{D}}=3.72\left\langle\mathrm{M}_{\mathrm{D} 1}=5.50, \mathrm{t}[39]=-6.173, p<\right.\right.$ 0.01 ).

\subsubsection{Perceived fit.}

$\mathrm{H} 1$ predicted that the effects of product number on the perceived fit and evaluations of an extended product would be moderated by brand breadth. As in Study 1, the results showed that, for a narrow brand, there was no significant difference in the perceived fit between the five-product and two-product brands $\left(\mathrm{M}_{\mathrm{A}}\right.$ $\left.=2.05, \mathrm{M}_{\mathrm{C}}=2.25, \mathrm{t}[39]=-1.749, p=0.09\right)$. 
For a broad brand, however, the perceived fit was significantly higher when the brand was associated with five products than when associated with two $\left(\mathrm{M}_{\mathrm{B}}=2.92<\mathrm{M}_{\mathrm{D}}=3.72\right.$, $\mathrm{t}[39]=-4.542, p<0.01)$. For a very broad brand, we found a significantly higher perceived fit for the five-product brand $\left(\mathrm{M}_{\mathrm{B} 1}=\right.$ $\left.1.97<\mathrm{M}_{\mathrm{D} 1}=3.27, \mathrm{t}[39]=-5.656, p<0.01\right)$, thus allowing us to extend the results of Study 1 to a brand with a very broad breadth.

To derive H1, we postulated that a narrow brand that adds similar products will be perceived as even narrower. Subjects indeed perceived Brand $\mathrm{C}$ narrower than Brand $\mathrm{A}$, but the difference did not reach statistical significance $\left(\mathrm{M}_{\mathrm{A}}=2.07, \mathrm{M}_{\mathrm{C}}=1.87, \mathrm{t}[39]=1.347\right.$, $p=0.186$ ). Unexpectedly, we found statistically significant differences in brand breadths between Brands $B$ and $D\left(M_{B}=4.65>M_{D}=\right.$ 3.72 , $\mathrm{t}[39]=2.975, p<0.01)$ as well as between Brands B1 and D1 $\left(\mathrm{M}_{\mathrm{B} 1}=6.23>\mathrm{M}_{\mathrm{D} 1}\right.$ $=5.50, \mathrm{t}[39]=3.375, p<0.01)$, suggesting that adding products to a broad brand could also produce the perception of a narrower brand breadth. In the case of Brands D and D1, however, these perceptions did not adversely affect the perceived fit of the extensions because the brand breadths were sufficiently broad from the beginning.

$\mathrm{H} 2$ predicted that the relationship between a brand's breadth and the perceived fit of a moderately far brand extension would look like an inverse- $U$ shape. We found a significant impact of brand breadth on perceived fit ( $F[2$, $234]=13.052, p(0.01)$. Planned contrasts reveal that, as expected, the narrow brand's extension obtained a significantly lower fit than the broad brand's $\left(\mathrm{M}_{\text {narrow }}=2.15<\mathrm{M}_{\text {broad }}=\right.$ $3.33, \mathrm{t}[79]=-5.986, p<0.01)$ and the broad brand's extension obtained significantly higher fit than the very broad brand's $\left(\mathrm{M}_{\text {broad }}=3.33\right.$ $>\mathrm{M}_{\mathrm{v} \text {, broad }}=2.63, \mathrm{t}[79]=4.625, p<0.01$ ), supporting $\mathrm{H} 2$ altogether. Figure 4 shows an inverse-U shaped relationship between brand breadth and perceived fit. We also analyzed the relationship for Brands A, B, and B1, each with two products but different breadths. The narrow brand's extension received a significantly lower fit than the broad brand's $\left(\mathrm{M}_{\mathrm{A}}=2.05<\right.$ $\left.\mathrm{M}_{\mathrm{B}}=2.93, \mathrm{t}[39]=-3.484, p<0.01\right)$ while the broad brand's extension obtained a significantly higher fit than the very broad brand's $\left(M_{B}=\right.$ $\left.2.93>\mathrm{M}_{\mathrm{B} 1}=1.98, \mathrm{t}[39]=4.848, p<0.01\right)$. For Brands C, D, and D1, each with five products, Brand C's extension obtained a significantly lower fit than Brand D's $\left(M_{C}=2.25<M_{D}=\right.$ $3.73, \mathrm{t}[39]=-4.960, p<0.01)$, while Brand D's extension received a higher fit than Brand D1's, the difference being only marginally significant $\left(\mathrm{M}_{\mathrm{D}}=3.73>\mathrm{M}_{\mathrm{D} 1}=3.28, \mathrm{t}[39]=\right.$ 1.988, $p=0.054)$.

\subsubsection{Evaluations of an extended product}

As in Study 1, we found the four items used to measure extended product evaluations to have 
〈Figure 4〉 Brand Breadth and Perceived Fit of an Extended Product

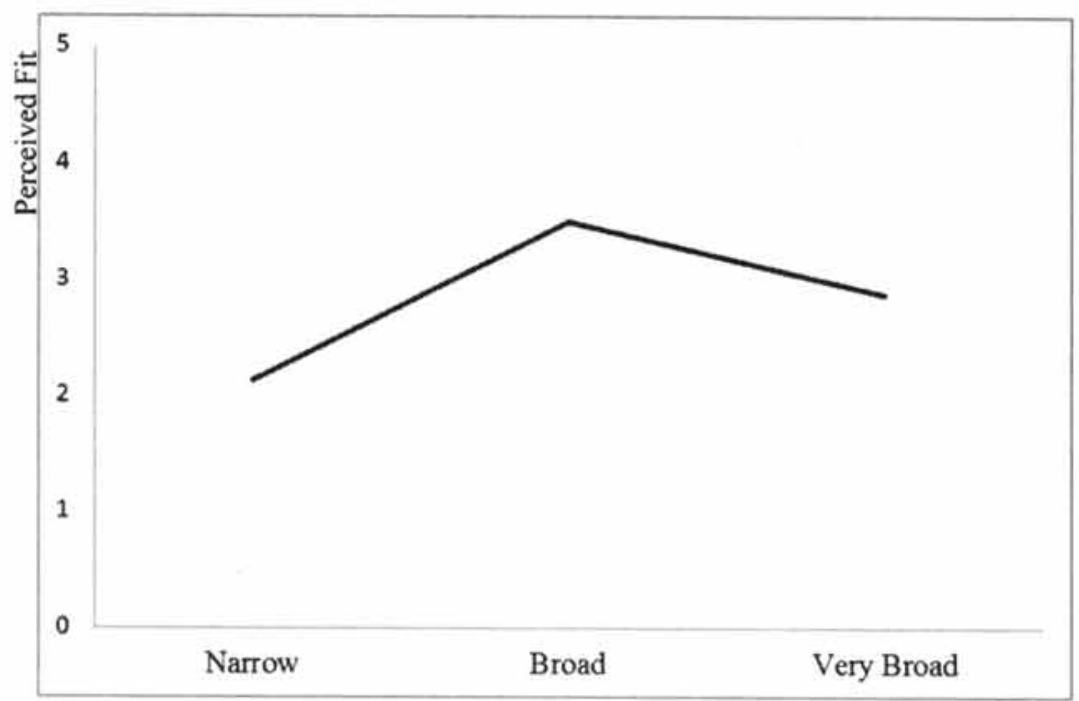

high reliability (Cronbach's $a=0.90$ ). We thus used the simple average of these items in further analyses.

We found that, for a narrow brand, the extended product from the five-product brand was not more favorably evaluated than that from the two-product brand $\left(\mathrm{M}_{\mathrm{A}}=2.04, \mathrm{M}_{\mathrm{C}}\right.$ $=2.24, \mathrm{t}[39]=-1.728, p=0.09)$. For $\mathrm{a}$ broad brand, however, the extended product was more favorably evaluated when the brand was associated with five products than when associated with two $\left(\mathrm{M}_{\mathrm{B}}=3.09<\mathrm{M}_{\mathrm{D}}=3.93\right.$, $\mathrm{t}[39]=-5.918, p<0.01)$. For a very broad brand, the extended product from the fiveproduct brand obtained more favorable evaluations $\left(\mathrm{M}_{\mathrm{B} 1}=2.19<\mathrm{M}_{\mathrm{D} 1}=3.58, \mathrm{t}[39]=\right.$ $-5.967, p<0.01)$. Study 2 , then, provided support for $\mathrm{H} 1$ in a setting wider than that in Study 1.

Regarding H2, we obtained a significant ef- fect of brand breadth on extension evaluations $(\mathrm{F}[2,234]=29.506, p<0.01)$. Consistent with our predictions, the narrow brand's extension obtained significantly lower evaluations than the broad brand's $\left(\mathrm{M}_{\text {narrow }}=2.14<\mathrm{M}_{\text {broad }}=3.51\right.$, $\mathrm{t}[79]=-10.539, p<0.01)$, while the broad brand's extension obtained significantly higher evaluations than the very broad brand's ( $\mathrm{M}_{\text {broad }}$ $=3.51>\mathrm{M}_{\mathrm{v}, \text { broad }}=2.88, \mathrm{t}[79]=4.247, p$ 0.01), supporting H2. Comparing Brands A, B, and $\mathrm{B} 1$, each with two products but different breadths, the narrow brand's extension received significantly lower evaluations than the broad brand's $\left(\mathrm{M}_{\mathrm{A}}=2.04<\mathrm{M}_{\mathrm{B}}=3.09, \mathrm{t}[39]\right.$ $=-6.129, p<0.01)$, while the broad brand's extension obtained significantly higher evaluations than the very broad brand's $\left(\mathrm{M}_{\mathrm{B}}=3.09\right.$ $\left.>\mathrm{M}_{\mathrm{B} 1}=2.19, \mathrm{t}[39]=5.166, p<0.01\right)$. Comparing Brands C, D, and D1, each with five products, Brand C's extension was less fa- 
vorably evaluated than Brand $D^{\circ}$ s $\left(M_{C}=2.24\right.$ $\left\langle\mathrm{M}_{\mathrm{D}}=3.93, \mathrm{t}[39]=-9.190, p<0.01\right)$, while Brand D's extension received more favorable evaluations than Brand $\mathrm{Dl}$ 's, in a difference without statistical significance $\left(\mathrm{M}_{\mathrm{D}}=3.93\right.$, $\left.\mathrm{M}_{\mathrm{DI}}=3.58, \mathrm{t}[39]=1.513, p=0.14\right)$. Overall, these results supported $\mathrm{H} 2$.

\section{Conclusions}

This paper was motivated by two gaps in the literature on brand portfolio planning. First, although research has investigated the effects of number of products associated with a brand and the effects of brand breadth separately. the two factors most likely interact. While previous studies have either controlled brand breadths and varied the product numbers or controlled product numbers and varied the brand breadths (e.g., Dacin and Smith 1994: Meyvis and Janiszewski 2004), they have not considered joint effects of product number and brand breadth. Second, the literature has investigated the effect of brand breadth on the perceived fit and evaluations of an extended product within a relatively limited range ("narrow vs. broad"), while some researchers have conjectured that a very broad brand risks being perceived as a "jack-of-all-trades," leading to the unfavorable evaluation of its extended product (e.g., Kardes and Allen 1991).
To address these gaps, we hypothesized that the effects of the number of products associated with a brand on the perceived fit and evaluations of a moderately far brand extension are moderated by the brand's breadth (H1) and that the relationship between a brand's breadth and a moderately far extension's perceived fit and evaluations would look like an inverse-U shape (H2). We conducted two experiments to test these hypotheses and found that both hypotheses were supported. Regarding H1, the extended product of a broad brand received more favorable evaluations when the brand was associated with more products, while the evaluations were not significantly different for a narrow brand. Regarding H2, the broad brand fared better than the narrow brand in the brand extension, while the very broad brand fared worse than the broad brand.

This paper contributes to the literature on brand extensions in two ways. First, it broadens our understanding of the effects of product number and brand breadth on extended product evaluations by considering the two factors jointly whereas previous research has treated them separately. Second, we believe this study to be the first to present evidence that brand breadth can exert an inverted U-shape effect on the perceived fit and evaluations of an extended product. Although Kardes and Allen (1991) conjecture that an extended product from a very broad brand risks being evaluated less favorably, little research if any has validated 
this view.

The results reported in this paper offer the following implications for marketers. First, marketers should heed the finding that adding similar products to a narrow brand does not help the brand's extension launch. To avoid the trap we have uncovered, marketers should take risks and proactively broaden their brand's breadth by introducing moderately far brand extensions. Second, the finding that the relationship between brand breadth and extended product evaluations might not be linear provides practical implications. While a narrow brand should not keep launching close extensions, nor should a broad brand continue producing far extensions to broaden its breadth. A firm with a broad corporate or family brand might want to consider introducing a new brand instead of adding dissimilar products under the brand umbrella. In this regard, one might say that Virgin's seemingly undisciplined brand extensions (Keller 2012) and Samsung's recent abolition of individual product brands (Kim 2011) might not bode well for these firms future brand extensions.

Finally, the results reported in this paper are subject to the following limitations and they provide avenues for further research. First, we measured brand breadth as the dissimilarity among products associated with a brand. Prior research had measured brand breadth merely as the dissimilarity among products (Meyvis and Janiszewski 2004: Kim, Cha and Chun 2009) or as the number of products available under a brand name (Sheinin and Schmitt 1994: Yeo and Park 1994). Developing a measurement scale for brand breadth that incorporates complementarities or technological relatedness would be worthwhile. Second, it would be fruitful to examine the psychological mechanism that makes consumers react less favorably to an extension from a very broad brand than that from a broad brand. More broadly, one might investigate variables that moderate the inverse- $\mathrm{U}$ shaped relationship between brand breadth and evaluations of brand extensions. Brand concept (Park, Milberg and Lawson 1991) or consistency of quality (Dacin and Smith 1994) could be potential candidates.

〈Received May 12. 2013〉

〈1st Revised July 31. 2013〉

〈2nd Revised September 16. 2013〉

〈Accepted September 20. 2013〉

\section{References}

Ahn, Hee Kyung and Young Won Ha (2001), "Corporate Brand as a Stereotype: Effects of Stereotype-Incongruent Information on Stereotype Change," Journal of Korean Marketing Association, 16, 109-134.

Boush, David M. and Barbara Loken (1991), "A Process-Tracing Study of Brand Extension Evaluation," Journal of Marketing 
Research, 28, 16-28.

Broniarczyk, Susan M. and Joseph W. Alba (1994), "The Importance of the Brand in Brand Extension," Journal of Marketing Research, 31, 214-228.

Dacin, Peter A. and Daniel C. Smith (1994), "The Effect of Brand Portfolio Characteristics on Consumer Evaluations of Brand Extensions," Journal of Marketing Research, 31, 229-242.

Jun, Sung-Youl, Jong-Ho Huh, and So-Hee Jang (2007), “The Effects of the Type of Brand Extensions on Evaluations of Target Extension Product in Dissimilar Extensions: Focusing on the Moderating Role of Brand Concept and the Price of Target Extension Product," Asia Marketing Journal, 9, 1-32. Kardes, Frank R. and Chris T. Allen (1991), "Perceived Variability and Inferences about Brand Extensions," Advances in Consumer Research, 18, 392-398.

Keller, Kevin Lane (2013), Strategic Brand Management, $4^{\text {th }}$ ed., Pearson Education.

Kim, Dae-Young (2011), "Samsung Will Not Use Pavv and Hauzen," Maeil Economic Daily, February 16.

Kim, Gwi-Gon, Tai Hoon Cha, and Seung Woo Chun (2009), "The Effect of the Salience of Product-Category Information on Brand Extension Evaluation: Across-Cultural Study about The Interference Effect of ProductCategory Information between Westerners and Easterners," Journal of Korean Mar- keting Association, 24, 29-50.

Liang, Beichen, Joseph Cherian, and Wei Fu (2010), "Can Followers Overcome Pioneers? The Role of Superior Alignable Differences in Consumer Evaluation of Brand Extensions," Journal of Product and Brand Management, 19, 85-93.

Loken, Barbara and Deborah Roedder John (1993), “Diluting Brand Beliefs: When Do Brand Extensions Have a Negative Impact?", Journal of Marketing, 57, 71-84.

Meyvis, Tom and Chris Janiszewski (2004), "When Are Broader Brands Stronger Brands? An Accessibility Perspective on The Success of Brand Extensions," Journal of Consumer Research, 31, 346-357.

Morrin, Maureen (1999), "The Impact of Brand Extensions on Parent Brand Memory Structures and Retrieval Processes," Journal of Marketing Research, 36, 517-525.

Park, C. Whan, Sandra Milberg and Robert Lawson (1991), "Evaluation of brand extensions: The role of product feature similarity and brand concept consistency," Journal of Consumer Research, 18, 185-193.

Ries, Al and Jack Trout (1981), Positioning: The Battle for Your Mind. New York: McGraw-Hill.

Sheinin, Daniel A, and Bernd H. Schmitt (1994), "Extending Brands with New Product Concepts: The Role of Category Attribute Congruity, Brand Affect, and Brand Breadth," Journal of Business Research, 31. 
1-10.

Sood, Sanjay and Kevin Lane Keller (2012), "The Effects of Brand Name Structure on Brand Extension Evaluations and Parent Brand Dilution," Journal of Marketing Research, 49, 373-382.

Tversky, Amos (1977), "Features of similarity," Psychological Review, 84, 327-352.
Yeo, Jun Sang and Jong Won Park (2004), "Interactive Effects of Breadth of Parent Brand and Product Category Similarity of An Extension on Attitudes Toward The Extension and Parent Brand Beliefs," Journal of Korean Academic Society of Business Administration, 33, 1397-1421.

Zajonc, Robert B. (1980), "Feeling and Thinking: Preferences Need No Inferences," American Psychologist, 35, 151-75. 


\section{〈Appendix〉Actual Stimuli Card used in Study 1*}

Shown below are products actually marketed by Brands A, B, C, and D. The real names of these brands are not disclosed by the requests of the companies. Please take note of this card and answer the questions.
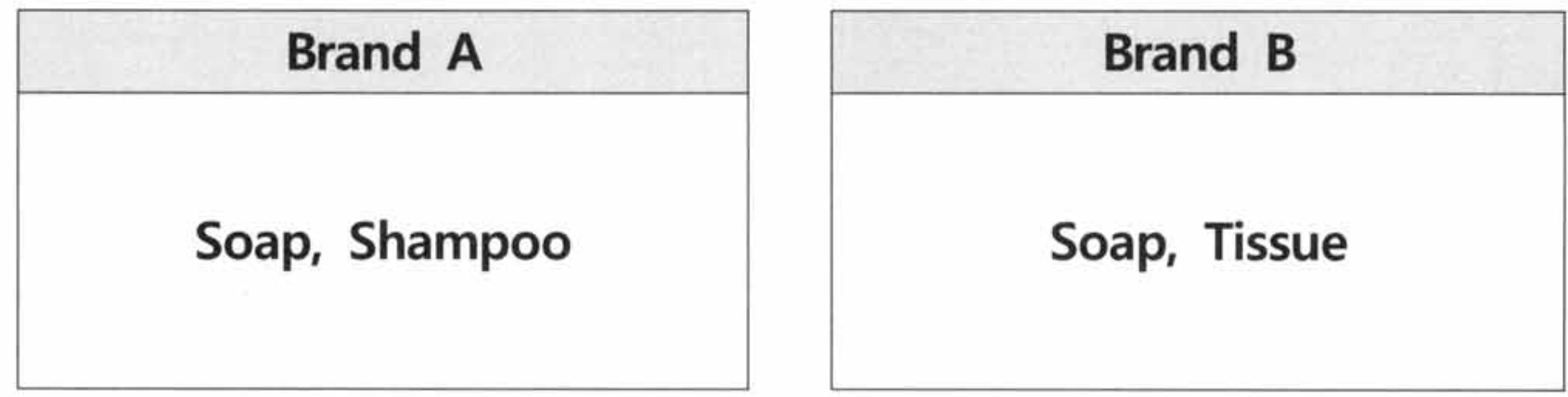

\begin{tabular}{|c|}
\hline Brand C \\
\hline Soap, Shampoo, \\
Hand Sanitizer, Body Wash, \\
Foam Cleanser
\end{tabular}

\begin{tabular}{|c|}
\hline Brand D \\
\hline Soap, Tissue, Air Freshener, \\
Fabric Softener, \\
Liquid Detergent
\end{tabular}

*The order of the four brands was varied to minimize the order effect. 